\title{
РАЗДЕЛ VІІ. СОЦИОЛОГИЯ
}

\section{Голиков С.B. \\ Принципы формирования и функционирования духовного пространства}

Уфимский государственный авиаџионный технический университет

(Россия, Уфа)

doi:10.18411/lj-09-2018-51

idsp: 000001:lj-09-2018-51

\section{Аннотация}

В статье рассматривается правомерность использования понятия «духовное пространство», определяется объективность существования данного термина и необходимость установления принципов духовного пространства общества. Предлагается классификация принципов функционирования и формирования духовного пространства и конкретизированная сущность каждого принципа.

Ключевые слова: духовное пространство, объективность, научное исследование духовного пространства, принципы формирования духовного пространства.

Концептуальное использование понятия «духовное пространство», богатого в смысловом и содержательном плане, помогает с позиции социологии оценить всю совокупность материальных и духовных объектов, с которыми взаимодействует население любого возраста и статуса на определенной территории или в регионе. Все духовные объекты тесно взаимосвязаны и ценностно ориентированы на социализацию и развитие духовной составляющей культуры населения. Духовное пространство не противоречит философскому представлению о пространстве, которое представляет всеобщую форму бытия материи и её важнейшие атрибуты. Абсолютного пространства в духовной сфере не существует. Духовное пространство неразрывно связано с социальным и историческим временем, определяемым историческим развитием общества. Время определяет структуру, характер и содержание духовного пространства общества. П. Бурдье оценил взаимосвязь пространства и времени как совокупность связей, которые формируют пространство позиций, внешних по отношению друг к другу и вместе с тем определяемых одна через другую, по их взаимной близости и отдалённости [1, с. 55.].

Научное исследование «духовного пространства» предполагает объективность существования данного термина. Объективность проявляется в выборе понятий, которые характеризуют содержание духовного пространства; в совокупности противоречий, раскрывающих формы и параметры духовного пространства в процессе их изменение в разные исторические периоды; в целевых установках, актуализирующих отдельные аспекты культурного развития населения внутри духовного пространства. Она позволяет определить количество, качество, степень распространения и типологию духовных ценностей, которые, в рамках духовного пространства, накапливаются и потребляются обществом, что будет способствовать определению принципов формирования и функционирования духовного пространства. Социология рассматривает принципы как наиболее сознательную форму использования объективных законов, отличающихся стабильностью во времени. Многомерность духовного пространства во времени и социальном развитии предполагает многообразие средств и способов его наполнения духовными ценностями и их потребления, и регулирование этих процессов на основе принципов.

В отношении принципов, прежде всего, следует ответить на вопрос: возможны ли универсальные принципы формирования духовного пространства, поскольку они должны распространяться и на область непознанного (и представляться, в этом случае, как 
априорные). Субъект создания и потребления духовных благ всегда имеет дело лишь с конечной областью познанного. Обнаружение объективной необходимости в истории человечества, связанной с улучшением жизнеобеспечения людей и упорядочением общественных отношений на каждом этапе развития и составляет, по нашему мнению, потребность в принципах. Исследование духовного пространства, его формирования, наполнения духовными ценностями и потребление духовных ценностей, предполагает классификацию принципов, которые отражают сущность реальных процессов духовной жизни общества. Они должны отличаться высокой временной стабильностью (для возможности сравнения состояния духовной жизни общества в историческом времени), что не исключает гибкости их применения в конкретных условиях. Учёт динамизма в изучении значимости отдельных принципов может считаться показателем духовной культуры. Научный уровень социологического подхода базируется на том, что принципы формирования, наполнения и пользования духовных благ имеют реальную основу в виде целой системы общественных зависимостей и рассматриваются как реальный исторический продукт, доступный для осознанного творчества.

В основу предлагаемой классификации принципов формирования и функционирования духовного пространства заложены два типа принципов, отражающих уровень обобщения знаний о духовном развитии общества: методологические и организационные принципы. В соответствии с методологическими принципами можно рассматривать все социальные и духовные процессы вне зависимости от общественного строя и политической системы, т. к. они отражают социологический аспект исследования духовного пространства:

-принцип объективности определяет независимость знания от конкретного человека. Принцип отражает суммарный результат взаимодействия реальных условий жизнедеятельности людей и их общественной практики;

- принцип социального детерминизма заключается в общественной обусловленности развития личности или группы, формирования её сознания и поведения в разных общественных системах. А это предполагает решение целого комплекса проблем, связывающих в единое целое многообразные аспекты изучение духовного пространства: взаимодействие внешней и внутренней (социально-духовной) детерминации, объективного и субъективного, материального и идеального;

- принцип дифференциации научного познания, необходимый для дифференцированного изучения отдельных явлений, взаимодополняющих друг друга. Принципиальное значение для сферы методологии заключается в широте номенклатуры применяемых методологических средств, что может привести к противопоставлению одних методов научного познания другим. Это снижает эффективность научных исследований духовного пространства, может привести к излишне узким исследованиям и неоправданному дублированию;

- принцип относительности знания отражает тесное взаимодействие материи, пространства, времени и движения. Материя есть абстракция, в которой отражена вся объективная реальность. Время и пространство являются категориями внешнего мира, т.к. отражают свойства материальных объектов, имеют всеобщий характер и ни одно материальное образование немыслимо вне времени и пространства, а движение является сущностью времени и пространства. Материалистическая диалектика считает, что относительные знания являются ступенями к постижению полного знания. Объективность принципа относительности знания обусловлена соответствием теоретических положений экспериментальным данным. Духовное пространство не может существовать вне времени и не может находиться в статичном состоянии. Постоянно действующие процессы внутри духовного пространства изменяют его содержание и форму;

- принцип полисистемности познания необходим для многомерного системного понимания духовного пространства. Чем выше достигнутый уровень 
познания явлений и процессов, приближающийся к выделению закономерностей объективного мира, тем глубже человек должен осознавать внешние взаимодействия между различными основаниями бытия. На современном уровне развития научного знания, при учете общих и специфических оснований, происходит расширение самих предметов познания. Непрерывность и многомерность пространства достигается постоянным взаимодействием элементов системы, причем начало последующего элемента включает в себя конец предыдущего [2, с. 239].

Такое понимание духовного пространства и процессов, происходящих в нём, когда каждая духовная ценность помимо индивидуального измерения приобретает ещё и «видовое» измерение, способно действительно расширить границы человеческого познания духовного пространства [3, с. 25]. Это важно для оценки социальной значимости наполнения, формирования и потребления духовного пространства духовными ценностями. Например, отдельные духовные ценности духовного пространства России могут принадлежать российскому менталитету, православной этике;

- принцип интегральности измерения духовного пространства в полной мере связан с системным подходом к исследованию, где исходным базовым признаком является интегральная целостность, а специфическим предметом изучения становятся интегральные свойства и закономерности духовного пространства [4, с. 28]. По нашему мнению, понятие «духовное пространство» фиксирует объектную форму целого общество, а понятие «интеграция» подчёркивает процесс и механизм объединения частей, приобретения интегральных совокупных качеств. Но оба понятия рассматривают интеграцию как общий параметр объективной действительности. Знание закономерностей интеграции духовного пространства - структурообразования, функционирования, развития, взаимодействия, наполнения и расходования - элемент качественного анализа состояния духовного пространства;

- принцип ценностной природы духовных отношений означает, что человек воспринимает явление или процесс, оценивает их с точки зрения, прежде всего, существующих норм, идеалов, интересов и ориентаций, выносит своё суждение, которое и определяет его дальнейшую творческую деятельность. Духовный капитал проявляет себя в совокупности интересов, знаний, стереотипов, установок, самоорганизации поведения. Духовный потенциал нужно понимать как источники, возможности, средства, которые могут быть задействованы в процессе духовного саморазвития и помощи в духовном становлении других людей. Соединение духовных ценностей, духовного капитала, духовного потенциала участвует в формировании духовного пространства и регуляции деятельности и поведения людей.

Организационные принципы призваны отражать внутренние процессы формирования и функционирования духовного пространства, которые определят его структуру, границы и механизмы изменений в определенный исторический период:

- принцип саморазвития, саморегулирования и самоорганизации обеспечивает систему духовного пространства источниками, движущими силами и механизмами самодвижения, которые способствуют успешному и устойчивому функционированию и самосовершенствованию системы, ориентированной на социальный и духовный прогресс;

- принцип конкретности означает использование объективных закономерностей и их специфического проявления в конкретных условиях, когда политические, философские и духовно-нравственные идеи обретают идеологическую форму массового сознания, становятся интересами масс;

- принцип научности заключается в особой форме отражения в сознании людей явлений природы, общественной жизни и мышления. При этом процесс научного познания осуществляется на основе преемственности, многосторонности и 
включает накопление фактов, описание явлений, открытие законов, формулирование теорий и гипотез развития общественных явлений и процессов, а также разработку новых методов познания и средств исследования.

- принцип преемственности определяет взаимосвязь формаций, передачи практического опыта поколений, восстановления взаимосвязей между различными звеньями общества;

- принцип внутренней свободы создания и потребления духовных ценностей. Личность человека самоопределяется посредством свободы. Но свобода основана на моральной и социальной ответственности. Нарастание вероятностных, стохастических процессов в современном социуме изменяет содержание экзистенции, которая затрагивает степень свободы выбора человека в принятии решений. Экзистенция как возможность выбора творческих возможностей человека лежит в основе мировоззренческой позиции личности [5, с. 33];

- принцип исторического характера духовных ценностей в духовном пространстве;

- принцип единства социальных целей и задач особенно важен при социальных и политических катаклизмах, смене управленческих ориентиров власти;

- принцип соотнесённости духовных ценностей в духовном пространстве с определёнными сторонами духовной жизни общества.

Предлагаемый нами набор принципов формирования и расходования духовного пространства страны нельзя считать абсолютным, т.к. частные принципы могут действовать не только на уровне духовного пространства страны, но и на уровне отдельных источников духовных ценностей (семьи, детских дошкольных учреждений, средних и высших учебных заведений, производственных предприятий, многочисленных государственных источников духовных ценностей).

$$
* * *
$$

1. Бурдье П. Социология политики. - М., 1993.

2. Трофимова Г. И., Черемисина В. Г. Духовное пространство // Международный научный журнал «Символ науки». 2016. № 1. С. 236-243.

3. Кузьмин В. П. Гносеологические проблемы системного знания. М.: Знание. Серия «Философия», 1983. № 11.

4. Гильманов А. 3., Давлетшина Л. А. Система профессиональной подготовки кадров монопрофильного города: социологический анализ. Акад. наук Республики Татарстан, Центр перспективных экономических исслед., Ин-т экономики, упр. и права (г. Казань). - Казань: Познание, 2014. - 123 с.

5. Бикметов Е.Ю., Кунгурцева Г.Ф. Метологические аспекты активизации культурно-интеллектуального потенциала современного менеджера // Вестник Пермского национального исследовательского политехнического университета. Социально-экономические науки. 2018. № 1. С. 23-36.

\section{Кафиев И.Р. \\ Профессиональная этика инженера}

Башкирский государственный аграрный университет (Россия, Уфа)

doi:10.18411/lj-09-2018-52

idsp: 000001:lj-09-2018-52

Аннотация

В статье рассматриваются сущность и принципы профессиональной этики инженера. Показана важность соблюдения в профессиональной деятельности инженера положений этических норм.

Ключевые слова: инженер, профессиональная этика, этические нормы, профессиональный долг. 